\title{
ARQUEOLOGÍA Y ETNOHISTORIA: DIÁLOGOS RENOVADOS EN TORNO A LAS RELACIONES ENTRE LAS SOCIEDADES DE LOS LLANOS RIOJANOS Y DE LAS SIERRAS NOROCCIDENTALES DE CÓRDOBA (PERÍODOS PREHISPÁNICO TARDÍO Y COLONIAL TEMPRANO)*
}

\author{
ARCHAEOLOGY AND ETHNOHISTORY: RENEWED DIALOGUES \\ AROUND THE RELATIONSHIP BETWEEN LOS LLANOS RIOJANOS AND \\ NORTH WESTERN CORDOBA'S MOUNTAIN SOCIETIES \\ (LATE PREHISPANIC AND EARLY COLONIAL PERIODS)
}

Sebastián Pastor ${ }^{* *}$ y Roxana Boixadós ${ }^{* * *}$

\begin{abstract}
Este artículo propone integrar dos líneas de investigación independientes. Por un lado, la arqueológica, que comprende el estudio del arte rupestre prehispánico y colonial temprano en las regiones del Noroeste de Córdoba y de Los Llanos de La Rioja. Por otro la etnohistórica, centrada en las sociedades de Los Llanos durante el período del contacto hispano indígena. La discusión entre ambas permite cuestionar la aceptada homogeneidad étnica, lingüística y cultural de esta región y plantear en cambio un panorama diferente de diversidad lingüística y cultural, con estrechas vinculaciones de sus pobladores con los de las sierras noroccidentales de Córdoba (entre otros).
\end{abstract}

Palabras claves: Arte rupestre, Etnohistoria, Los Llanos de La Rioja, Noroeste de Córdoba.

This article proposes to integrate two independent lines of research. On the one hand, archaeological analysis of rock art in the early pre-Hispanic and colonial period in Northwestern's Córdoba region and Los Llanos de La Rioja. On the other, ethnohistorical approach, focusing on societies of Los Llanos during the Hispanic-Indian period. The discussion between both lines calls into question the accepted ethnic, linguistic and cultural homogeneity of Los Llanos region and propose instead a different picture of linguistic and cultural diversity, including close ties with the societies of northwestern's Cordoba region (among others).

Key words: Rock Art, Etnohistory, Los Llanos de La Rioja, Northwestern's Córdoba region.

\section{Introducción: las fuentes coloniales y los "olongastas" como problema}

En 1932 Rosario Vera Peñaloza evocaba en sus escritos a Los Llanos de La Rioja (Argentina), comentando acerca de uno de sus pueblos que ... lleva nombre indígena: Malanzán. Acaso huarpe, quizá comechingón o diaguita, puesto que todas las tribus confundieron sus dominios en el sur de La Rioja $^{1}$. Nacida en Atiles, antiguo pueblo de indios situado a $8 \mathrm{~km}$ de Malanzán, y descendiente de familias locales de raigambre colonial, la "Maestra de la Patria" reprodujo un saber popular de lejanos orígenes que aludía al carácter multiétnico de la población nativa. La idea de la "confusión de dominios" entre diferentes "tribus" puede referir a la coexistencia de varios grupos de distinta procedencia (huarpes, comechingones, diaguitas) en un mismo espacio geográfico en el pasado, como al mestizaje entre ellos. Ya entonces la diversidad de la toponimia llanista parecía guardar indicios silenciosos acerca de antiguas presencias superpuestas o de convivencias de población que distintos autores trataron de descifrar.

Frente a este retrato multiétnico de Los Llanos prehispánicos se consagró otro construido en el marco del saber científico. Salvador Canals Frau, uno de los primeros etnólogos y etnohistoriadores

\footnotetext{
* Investigación financiada por PIP CONICET 112-200801-02678, el PICT ANPCyT 2012-1614 y la Universidad Nacional de Quilmes.

** Centro de Estudios Históricos "Prof. Carlos S.A. Segreti", Área de Arqueología. CONICET. Córdoba, Argentina. Correo electrónico: pastorvcp@yahoo.com.ar

*** Universidad de Buenos Aires. Universidad Nacional de Quilmes. CONICET. Buenos Aires, Argentina. Correo electrónico: roxboixados@gmail.com
} 
de la etapa formativa de la antropología argentina, postuló en 1950 la existencia de los olongastas, grupo étnico diferenciado por su lengua, cultura y tradición de sus vecinos huarpes, comechingones, sanavirones, diaguitas y capayanes. Sumaba así un rasgo más al carácter singular de una región de consolidada identidad, cuna de dos caudillos decimonónicos de gran proyección en el escenario político nacional: Juan Facundo Quiroga y Ángel Vicente Peñaloza. Desde entonces, la relación olongastas-Los Llanos no fue revisada ni tampoco la existencia misma de esta "etnia" circunscrita a su entorno. La propuesta contaba con respaldo académico y cristalizaba expectativas respecto de la definición de la identidad regional.

Este trabajo, avance de una investigación en curso, tiene como objetivo revisar las ideas de Canals Frau de la región llanista poniendo en diálogo la producción de conocimientos desde la Etnohistoria y la Arqueología. Por un lado nos proponemos recuperar los aportes de otros investigadores y confrontarlos con el análisis de fuentes coloniales. Esta estrategia pone a prueba la existencia de los olongastas y descubre posibles relaciones entre grupos en una escala espacial más amplia. Por otro, el análisis comparado del arte rupestre prehispánico de Los Llanos riojanos y de las sierras noroccidentales de Córdoba (Serrezuela, Guasapampa y Pocho) interroga acerca de los vínculos interregionales en el pasado remoto, pero con proyección hacia el período de contacto hispano indígena. Los aportes de Canals Frau resultan entonces un punto de partida para repensar, en varias dimensiones de análisis, las dinámicas de relación entre diferentes poblaciones nativas que se interrumpieron o modificaron de manera sustantiva a partir de la conquista española.

En la prolífica obra de Salvador Canals Frau, desarrollada desde mediados de la década de 1930 hasta fines de 1950, encontramos una enorme diversidad de intereses y también denominadores comunes: la articulación entre estudios arqueológicos y el análisis de fuentes históricas y los estudios referentes a poblaciones indígenas prehispánicas por áreas culturales o regiones. Dentro de este panorama, un conjunto de trabajos se centran en pueblos o grupos étnicos "desaparecidos" (extinguidos o mestizados) a partir del proceso de conquista. Huarpes, pampas, capayanes y olongastas (entre otros) fueron vectores que guiaron búsquedas en archivos locales y de países limítrofes, en denodados esfuerzos por localizar y discutir fuentes tempranas que contuvieran rastros sobre ellos. Canal Frau combinó exhaustivas investigaciones en archivos con trabajos arqueológicos y estudios de orden lingüístico con el fin de determinar localizaciones geográficas, áreas de influencia o dispersión, idioma y cultura.

Apoyándose en la corriente teórica que dominaba el campo de la Antropología en esta etapa (la escuela Histórico-Cultural, afín al Difusionismo alemán), Canals Frau procuró establecer las bases de la identificación de las poblaciones nativas prehispánicas en nuestro país en relación con áreas culturales que tenían localizaciones más o menos precisas y que se reconocían a partir de rasgos compartidos, como la cultura material, la organización sociopolítica y el idioma (Lazzari 2002, 2004; Soprano 2009; González 2013; Zabala 2013). La identificación de un área, una cultura material más o menos homogénea y un idioma bastaban como indicadores para reconocer pueblos o grupos étnicos como unidades de análisis, cuya existencia se esfumaba paulatinamente tras el avance de la colonización. Los olongastas se encontraban entre los casos "rescatados del olvido" que fueron restituidos a su espacio original.

Los olongastas habrían habitado la antigua región llanista, de peculiar fisonomía geográfica: dos cadenas montañosas de baja altura, de disposición longitudinal y paralelas en la mayoría de sus tramos, rodeadas de amplios desiertos salitrosos conocidos como "travesías", verdaderas barreras aislantes que perfilaron a la región encerrada sobre sí misma. Como señala Canals Frau, los primeros españoles que atisbaron la zona en sus recorridas desde las ciudades de Mendoza y San Juan hacia el corazón del Tucumán, y desde Santiago del Estero, Tucumán y Córdoba hacia Cuyo, bordearon sus contornos sin entrar de lleno en ella. Un clima semidesértico, con escasas precipitaciones y cursos de agua permanentes no hacía de ella un espacio de interés para los conquistadores, atraídos por tierras más ricas y pobladas. Esto explica en buena medida la escasez de fuentes históricas y con ello las pocas oportunidades para rediscutir el "caso olongasta"2. Pero ese mismo contexto le confiere un valor particular a las pocas referencias tempranas que registraron el término o que aludieron a sus habitantes.

Así es como un documento temprano producido desde Mendoza constituye el "hallazgo" que testimonia la existencia de los olongastas. La mención aparece en relación con el relato de un sacerdote quien asentó que los nativos locales se referían a la zona llanista como "ulungasta", término que al 
parecer asociaban al particular idioma que hablaban sus habitantes. Este "dato" ponía orden a la diversidad toponímica regional, de difícil asociación con los idiomas de otros grupos de la zona mejor conocidos por los conquistadores (como allentiac, milcayac, camiare o kakano). La diversidad fue interpretada por Canals Frau en clave de diferenciación y desde ella postuló la singularidad de un pueblo que habitaba en una zona semiaislada y que hablaba igualmente un idioma particular: el olongasta.

Si bien esta propuesta corresponde a una etapa de madurez del autor su base empírica es bastante endeble. Las fuentes, aunque tempranas, ofrecen información de incierta corroboración, tomada de intérpretes nativos que solamente aportaron el término "ulungasta" en referencia a una región situada hacia el este de la jurisdicción mendocina, de remota e imprecisa localización. La terminación "gasta", expresión equivalente a pueblo en lengua kakana (diaguita) de acuerdo con varios autores, ni siquiera fue problematizada por Canals Frau quien apostó a consolidar el modelo de áreas culturales con un nuevo "descubrimiento"3.

Después de la publicación de este breve artículo Canals Frau no volvió a retomar el tema y su trabajo posterior se orientó a cuestiones más generales. Tampoco la propuesta recibió críticas ni convalidaciones por parte de otros autores. Los olongastas quedaron asociados al pasado prehispánico de Los Llanos riojanos y, con el tiempo, un sinnúmero de reiteraciones se encargaron de consagrarlos, respaldadas por la "autoridad del autor".

Sin embargo, en 1942 Juan Alfonso Carrizo había publicado en su Cancionero popular de La Rioja una propuesta diferente, no considerada por Canals Frau. Carrizo consultó otras fuentes documentales y bibliográficas, recorrió la zona palmo a palmo y fue un observador atento, de oídos abiertos para escuchar los relatos y testimonios de la gente respecto de las tradiciones del pasado. Con estos elementos planteó que la región había sido habitada en tiempos prehispánicos por poblaciones de origen diaguita, sanavirón y huarpe. La toponimia fue, en buena medida, la base de esta idea, a partir de ella reconoció zonas geográficas asociadas a portadores de una lengua o idioma. Así, y a grandes rasgos, en las zonas serranas identificó topónimos finalizados en "an" o "man" (Puluchán, Malanzán, Colosacán, Ichán, etc.) asociados con localizaciones en altura, y otros terminados en "vil" (Ambil, Niquivil, etc.), relacionados con la presencia de agua en sus proximidades, todos en lengua diaguita (kakana). En los faldeos orientales de las sierras de Los Llanos situó a las "parcialidades" sanavironas, las mismas que poblaban el noroeste de Córdoba -según había afirmado el padre Lozano- tomando como indicador clave la terminación "acate" (como Nacate). Carrizo notó además semejanzas entre ciertos topónimos localizados en ambas regiones, vecinas entre sí, como Tama y Tasma, Ambil y Ambul, etc. Finalmente, en la zona situada al sur de la sierra occidental ubicó a los huarpes, dada la proximidad con San Luis provincia poblada por estos indios, cuyo dominio se extiende por todo Cuyo según lo da a entender el padre Cabrera (Carrizo 1942: 27-29). Notemos que para Carrizo la zonificación regional según una adscripción por lengua y población expresa la coexistencia de poblaciones de distinto origen en espacios próximos y colindantes, sin plantear la superposición o el mestizaje entre ellas.

Hasta el momento no conocemos estudios acerca de la presencia huarpe en Los Llanos. En cambio, la relación entre los pueblos llanistas y los de las sierras del noroccidente de Córdoba ha sido señalada por varios autores. El historiador jesuita Pedro Lozano narró la expedición de pacificación a los partidos de tavasquiniguitas y mogas, situados en la Sierra Grande al mando del capitán Tristán de Tejeda en 1591, quien se había valido de los vencidos para que lo guiasen por el camino de las "salinas", donde descubrió en aquella comarca los indios escalacanites y yamanaes (Lozano 1874, IV: 398-399). Pero ese mismo año se fundó la ciudad de La Rioja y el gobernador rápidamente dispuso que Los Llanos fuera integrada a su jurisdicción para poder beneficiar a los nuevos vecinos con encomiendas. La referencia de Lozano ya advierte el vínculo que los nativos de las Sierras de Córdoba tenían con los habitantes de las Salinas Grandes, zona próxima a Los Llanos, en el período de contacto hispano indígena. Estas conexiones fueron reconocidas por Josefina Piana en su clásico estudio de la sociedad colonial temprana de Córdoba, al analizar un conjunto de litigios sostenidos por encomenderos de las jurisdicciones de San Luis, La Rioja y Córdoba en las últimas décadas del siglo XVI debido a la estrecha relación étnica de los indígenas de esas jurisdicciones con los de la zona occidental de Córdoba (Piana 1992: 148). La autora destacó la existencia de vínculos de carácter étnico (previos y activos durante la conquista española) entre los pobladores de un extenso espacio 
que durante décadas fue confín y frontera de las tres jurisdicciones coloniales.

Por lo demás, la publicación en 2008 del libro de Aníbal Montes Indígenas y conquistadores de Córdoba dio a conocer valiosa información documental y artículos producidos por el autor durante la década de 1950, de los que solo algunos habían sido publicados. Alejado de los modelos que la Antropología del momento sostenía, Montes analizó minuciosamente las fuentes del Archivo Histórico de Córdoba y realizó estudios sobre el terreno para recabar información. Varias son las conclusiones originales que el autor planteaba entonces pero dos de ellas resultan centrales para nuestra problemática. En primer lugar, la coexistencia de poblaciones de distinto origen en los mismos espacios geográficos y las posibles relaciones entre ellas derivadas de migraciones, conquistas y ocupaciones estacionales vinculadas al acceso a ciertos recursos. Al centrar el interés en la perspectiva histórica de las relaciones entre poblaciones nativas, Montes eludió caer en las rígidas localizaciones espaciales (y sus límites) establecidas por otros autores y las nociones asociadas a las "áreas de dispersión", concibiendo el medio social de modo dinámico. En segundo lugar, al reconocer la importancia del contexto de producción de las clasificaciones étnicas y lingüísticas que las fuentes coloniales tempranas registran, pudo advertir el bi o el multilingüismo de la población nativa y llamó la atención respecto de los procesos de traducción que con mayor o menor pericia realizaron los mediadores indígenas, mestizos o españoles. Este enfoque complica el valor heurístico que se le había atribuido a los topónimos, etnónimos, antropónimos y nombres de idiomas alentando a problematizar las relaciones entre ellos, sus posibles significados y los contextos discursivos en los que aparecen. Si bien estos planteos y recaudos metodológicos están hoy integrados a los modelos de análisis de fuentes del período de contacto hispano indígena (Martínez 1992), resultaron novedosos en una etapa en la que aún prevalecían especulaciones y apelaciones reiteradas y acríticas a autoridades consagradas de fines del siglo XIX y comienzos del XX.

Así, el análisis de los testimonios documentales tempranos (sobre todo litigios, cédulas de encomiendas y visitas) permitió a Montes constatar que en la región noroeste de Córdoba convivían poblaciones de filiación camiare ("comechingón"), sanavirona y diaguita (Montes 2008: 67-80 y 524-542). Minuciosos estudios comparados de la toponimia revelaron sorprendentes repeticiones y semejanzas de formas nominativas de pueblos y parajes, como así también nombres propios de caciques o de indios del común ${ }^{4}$. Montes localizó además un conjunto de cédulas de encomiendas otorgadas desde Córdoba que comprendían asentamientos en tierras llanistas, siendo la población local repartida en encomiendas junto con sus vecinas de las "Sierras Grandes". Las malocas, los traslados forzados de población y las cédulas que consignaban nombres de pueblos y caciques en diferentes lenguas o con ubicaciones imprecisas dieron lugar a pleitos entre encomenderos de finales del siglo XVI donde aparecen declaraciones de los nativos ${ }^{5}$. Estos testimonios recuperan atisbos de las relaciones que mantuvieron las poblaciones serranas de las dos regiones, separadas por la travesía que recorrían unos y otros en tiempos de la recolección de la algarroba. Compartir el acceso a este recurso básico de subsistencia supone la existencia de lazos sociales profundos, arraigados, posiblemente basados en el parentesco o en comunes pertenencias ${ }^{6}$.

La información referente a la población llanista prehispánica proviene en su mayoría de fuentes cordobesas; las riojanas son casi inexistentes ${ }^{7}$. El Archivo de Indias de Sevilla guardó por siglos un único expediente que contiene la cédula de encomienda de los pueblos llanistos de Puluchán y Tulain, una copia de la visita realizada en 1611 por el oidor Francisco de Alfaro a estos pueblos y el testimonio de una segunda visita realizada en 1623, donde se advierten los acelerados cambios ocurridos en estas pequeñas comunidades durante esta etapa ${ }^{8}$.

La visita de Alfaro revela que la encomienda comprendía dos pueblos, Puluchán y Tulain, topónimo este que tiene mucha semejanza con Tulián, pueblo y "provincia" situada en el noroeste de Córdoba y enfrentada con Los Llanos riojanos. Tomando como referencia el carácter multiétnico de las encomiendas que comprendían pueblos situados en las sierras cordobesas, tal como Montes ha documentado, podemos pensar que este sería un caso similar: la encomienda llanista otorgada desde La Rioja comprendía dos pueblos en Los Llanos, uno de posible filiación diaguita (Puluchán) y otro relacionado con las poblaciones camiare de Tulián-Cabiche (Tulain) del noroeste de Córdoba.

Si bien en 1611 los indios de Tulain (también nombrado "Tulaen") eran apenas dos (Lorenzo Pulanta e Isabel Achila, viuda) y residían en la ciudad con el encomendero junto a otros indios oriundos 
del pueblo de Puluchán, en 1623 ya no quedaban referencias al pueblo de Tulain o a su gente. Empero, una revisión atenta de los dos padrones muestra "apellidos" indígenas que evocan procedencias distintas. Por un lado, aquellos que se repiten en otros pueblos de indios de filiación diaguita o calchaquí (como Ampamam, Chumincha, Chantan, Sapatay, Yanape, Yanagui, Chumas, Cayuta, Tominsa, Banichay, etc.) y los que se asemejan a las listas que recupera Montes de las encomiendas del noroeste cordobés (Canta Hanan, Yacalto, Cantacalo, Socoton Nicha, etc.). En esta región Montes reconoció más de una docena de topónimos que comienzan con el prefijo "Canta" (entre ellos el pueblo de Cantacalo, en las sierras de Serrezuela al sudoeste de Tulián) como igualmente varios nombres de caciques ${ }^{9}$. También en los pueblos llanistas Cantacalo era nombre de caciques; uno de ellos fue registrado en Olta en 1589, y en el mismo Puluchán don Juan Cantacalo figura en la visita de 1623 como sucesor del cargo. La presencia en estos pueblos de personas nombradas con el prefijo "Canta" sugiere al menos la intervención de pobladores de comarcas cordobesas y una convivencia $-\mathrm{y}$ mestizaje- que la conquista española habría acentuado ${ }^{10}$. Si reparamos además en que varios de ellos eran caciques, se puede inferir que tal intervención pudo incidir en la organización política local.

Volviendo al pueblo de Tulain, no conocemos su localización precisa pero es probable que se encontrara en las proximidades de Puluchán, en el contiguo valle de Acalo o Nacate, designaciones estas que también aparecen como topónimos y antropónimos en el noroeste de Córdoba. En el valle de Acalo se localizaba el pueblo de Tuani, centro de una extensa merced otorgada a principios del siglo XVII al encomendero de los pueblos de Polco y Patquía (Hernando de Arroyo Illanes) y cuyos descendientes dividieron y vendieron parcelas en distintos momentos, generándose varios pleitos por la fijación de linderos y mensuras. Hacia 1760 las memorias de los pobladores locales, convocados para esclarecer el conflicto, no lograron esclarecer dónde se encontraba el pueblo de Tuani, aunque los testigos recordaron que en esa zona en disputa habían habitado los "indios quininguitas", encomendados a Alonso Díaz Caballero, vecino de Córdoba (Boixadós y Farberman 2011). ¿Los recordaban justamente porque se trataba de población foránea o de población que había sido trasladada a la jurisdicción cordobesa? Las respuestas no son excluyentes, ya que pueden dar cuenta de dos procesos inscritos en las tramas de relaciones interétnicas prehispánicas y de las transformaciones derivadas de la conquista española. Es posible que el Tulain prehispánico próximo a Puluchán coincida con el impreciso Tuani colonial, tempranamente despoblado y sus habitantes trasladados a Córdoba o a la reducción colonial de Puluchán.

Observemos que la memoria tardocolonial sobre los "quininguitas" engarza con el relato que aporta Lozano acerca de la expedición realizada por el capitán Tristán de Texeda (1591) hacia los partidos de tavasquiniguitas y mogas, situados en la Sierra Grande con el fin de apaciguar a sus pobladores rebeldes. ¿Estos "partidos" se extendían más allá de las Sierras Grandes, denominación aplicada en forma genérica a las Sierras de Córdoba, para alcanzar territorios ubicados en las Sierras de Los Llanos? Si fue así es muy posible que Los Llanos albergara a poblaciones que huían del avance de la conquista hacia territorios aún libres y abiertos a la recepción sobre la base de conexiones previas. Según los datos recabados por Montes, "Tininguita" ("quininguitas") era el nombre que los nativos del oeste cordobés empleaban para designar a la vecina sierra de Los Llanos.

La información reunida hasta ahora nos permite cuestionar la homogeneidad étnica, lingüística y cultural de los llanistos prehispánicos y esbozar un panorama diferente de diversidad lingüística y cultural, y estrechas vinculaciones con pobladores de las sierras noroccidentales de Córdoba (entre otros). En una escala diferente esta hipótesis incorpora y dialoga con la interpretación de Aníbal Montes para las Sierras de Córdoba, respecto de la convivencia de grupos de habla camiare (comechingones) con otros que se instalaron más tarde en diferentes sectores de su territorio, como diaguitas y sanavirones. En conjunto, una mirada más amplia que ponga en relación estas propuestas con los aportes recientes de investigaciones arqueológicas en estas regiones y sus sociedades prehispánicas nos permitirá aproximarnos a comprender mejor cómo y desde cuándo todas las tribus confundieron sus dominios en el sur de La Rioja.

\section{Una aproximación desde el arte rupestre}

El conocimiento de los procesos históricos del período prehispánico en la región de Los Llanos riojanos se ha visto limitado por el escaso desarrollo 
y discontinuidad de las investigaciones arqueológicas. Nuestra agenda de trabajo apunta a revertir este panorama, como objetivo de largo plazo que exige un abordaje en diferentes áreas, tipos de contextos y líneas de información. En este marco, y de acuerdo con la problemática tratada en este aporte, resultan de particular relevancia los estudios de arte rupestre, con los que se ha alcanzado un suficiente grado de avance como para delinear tendencias generales.

El arte rupestre comprende al conjunto de imágenes grabadas o pintadas en soportes rocosos de diversas características (aleros, cuevas, paredones, bloques a cielo abierto) y distribuidos en diferentes tipos de lugares (poblados, sendas, aguadas, territorios de caza). En el caso de Los Llanos constituye una de las materialidades conspicuas del período prehispánico y fue probablemente la que concitó el mayor interés entre los estudiosos que recorrieron la región (Aparicio 1939; Cáceres Freyre 1956-57; Fallabrino 1971). La investigación arqueológica contemporánea reconoce la importancia de su análisis en relación con múltiples intereses y preguntas, con una variedad de formas de abordaje e interpretación (Fiore 2009). En cuanto a nuestros interrogantes actuales se plantea que su estudio resulta clave con relación a diferentes problemas y escalas de indagación. A un cierto nivel se constituye en una línea privilegiada para comprender la compleja trama de construcción de lo local, por ejemplo la variabilidad en torno a la ocupación y significación de los diversos paisajes y tipos de lugares. El conocimiento de esta trama podrá ser profundizado con la investigación de otras líneas concurrentes, como estudios tecnológicos, de patrones de asentamiento y bioarqueológicos. En otra escala constituye la línea más firme para introducirse al problema de la vinculación de las comunidades locales con sociedades extrallanistas, a partir de la circulación de códigos visuales y formas materiales, como proyección de prácticas sociales e ideologías compartidas. Desde esta perspectiva se puede evaluar si las características del arte rupestre llanisto son puramente locales o, por el contrario, si existen elementos comunes con regiones vecinas, cuáles son estos elementos, en qué frecuencia se presentan y por dónde se distribuyen.

Según el conocimiento actual, basado en casi 30 sitios con arte rupestre prehispánico, disperso en diferentes áreas de la región llanista, se define un panorama de alta variabilidad que no obstante puede ser resumido en el predominio de dos formas principales. El concepto de "modalidad estilística" será importante para individualizar elementos comunes y retener aquellos que singularizan a cada producción rupestre particular. La modalidad estilística comprende patrones de representación, de selección de emplazamientos y usos semejantes de los soportes, en una trama relativamente sincrónica y preservando la posibilidad de incluir estilos distintos y coexistentes dentro de cada modalidad. Se flexibiliza así el concepto de "estilo" para abarcar la variabilidad potencial existente en un espacio determinado, articulando los elementos que circulan de "quebrada a quebrada", en tanto información compartida en un determinado lapso (Aschero 2006). Respecto de este lapso, la información cronológica es insuficiente no obstante el conjunto de indicios sugiere que el ciclo de producción del arte rupestre llanisto fue relativamente tardío, abarcando aproximadamente los últimos 800 o 1000 años anteriores a la conquista española. En comparación con otros escenarios regionales, como la Puna o la Patagonia, donde el arte rupestre experimentó varios milenios de desarrollo, en estas serranías estaríamos enfocando un proceso temporalmente acotado. Por el contrario, para la escala en la que se sitúan las preguntas derivadas de la lectura de las fuentes coloniales, ocho siglos o un milenio resulta un período muy prolongado, de larga duración, suficiente para identificar conexiones estructurales, construidas, reproducidas y asimismo transformadas a lo largo de generaciones por las sociedades investigadas.

La primera modalidad estilística ("El Salto") comprende grabados sobre paredones y bloques a cielo abierto, en emplazamientos que implican una amplia exposición de las imágenes (Figura 1). En ocasiones esta condición fue enfatizada con la ejecución de motivos grandes y en posiciones altas, lo cual favorece la visibilidad desde cierta distancia o por parte de numerosas personas en simultáneo. Las técnicas comprenden diversos procedimientos como el raspado, abrasión, horadación e incisión, en parte influenciados por el tipo de motivo a ejecutar y por las características litológicas del soporte. En cuanto al repertorio iconográfico predominan los motivos no figurativos, tanto simples como complejos. Entre estos últimos se destacan algunos por una mayor inversión en su confección, así como por su tamaño y posición en los soportes. Es probable que tuvieran un carácter emblemático, con un diseño ocasionalmente inspirado en la decoración textil. Los motivos zoomorfos son menos 

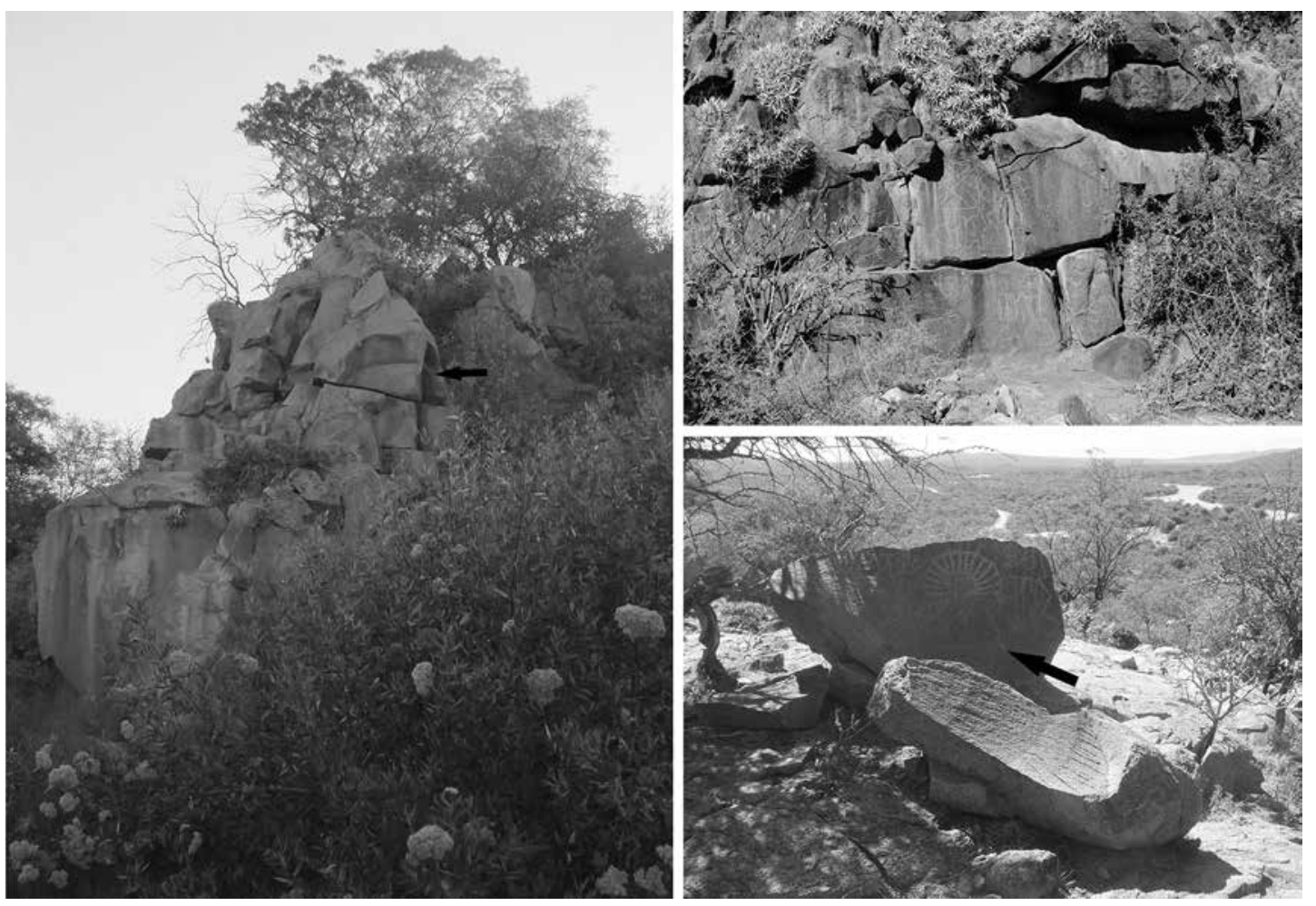

Figura 1. Elección de soportes de alta visibilidad para la ejecución de grabados de la modalidad estilística "El Salto".

comunes y con frecuencia fueron representados por sus huellas (de aves, de felinos, de camélidos). Otros motivos sobresalientes son mascariformes, cabezas con adornos y representaciones aisladas de objetos como adornos cefálicos. Estos motivos son entendidos como referentes colectivos, por ejemplo entidades ancestrales o emblemas de mando, con un elevado capital simbólico e influencia en la demarcación de los lugares en los que se encuentran, así como en la constitución de los sujetos que concurrían y participaban de los códigos que los significaban (Figura 2). En general estos lugares se relacionan con cauces por los que discurren arroyos estacionales, en concreto con segmentos donde el fondo rocoso permite el represamiento natural. Los grabados circunscriben el entorno de estos puntos de acumulación hídrica, o bien anuncian la aproximación e inminencia de los mismos, en el contexto del desplazamiento y circulación por el paisaje. Pocas veces se relacionan con sendas y puntos de alta visibilidad en las cimas de lomadas. Este conjunto de expresiones se distribuye con preferencia en las zonas bajas de las sierras $(c a$. 500-800 msm), en áreas acotadas y discontinuas de las costas Alta, Baja y del Medio, así como en sectores del valle del Medio (Figura 3).

La segunda modalidad ("El Chilcal") corresponde a pinturas ubicadas en aleros y cuevas que generalmente cuentan con posibilidades de reparo. En la mayoría de los casos estos emplazamientos confieren una visibilidad baja a las imágenes, que solo pueden ser observadas por quienes ingresan al interior (Figura 4). A diferencia de la modalidad anterior este tipo de arte interpeló a pocos observadores en simultáneo, quienes debieron ubicarse a corta distancia de las representaciones. Su producción y significación atañe al ámbito íntimo de la ocupación de estos refugios, en tanto acciones que resultaban invisibles desde el exterior. Este patrón se opone al carácter "público" de las expresiones de la modalidad "El Salto", a partir de sus condiciones de alta exposición en lugares a cielo abierto. Como mencionamos las técnicas de ejecución corresponden a pinturas, con empleo de colores como el rojo, blanco, negro y amarillo (en ese orden de importancia). Los motivos zoomorfos predominan en el repertorio, con un protagonismo absoluto de los camélidos (Figura 5). En escasa 


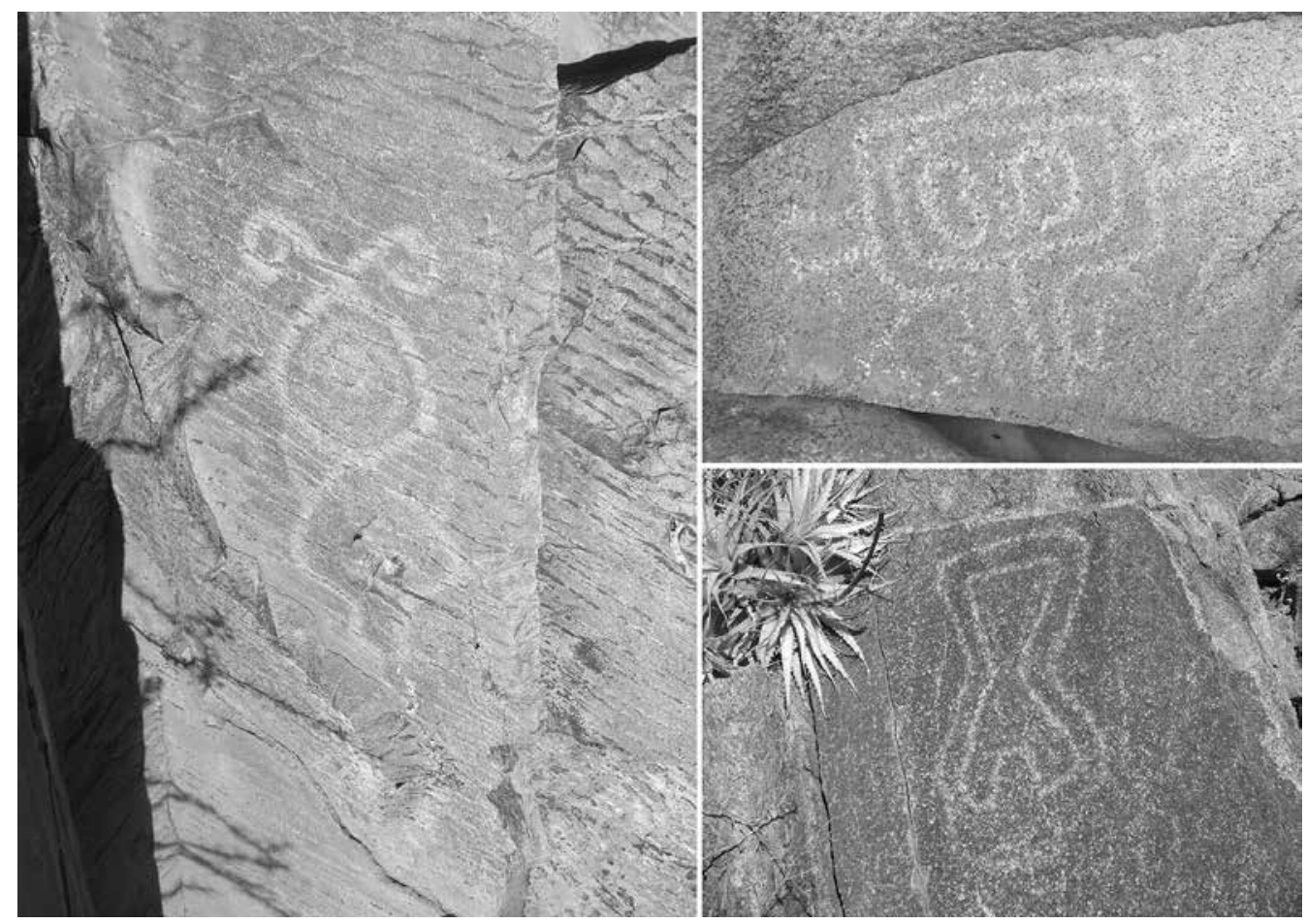

Figura 2. Grabados de la modalidad "El Salto" en sitios de Los Llanos de La Rioja.

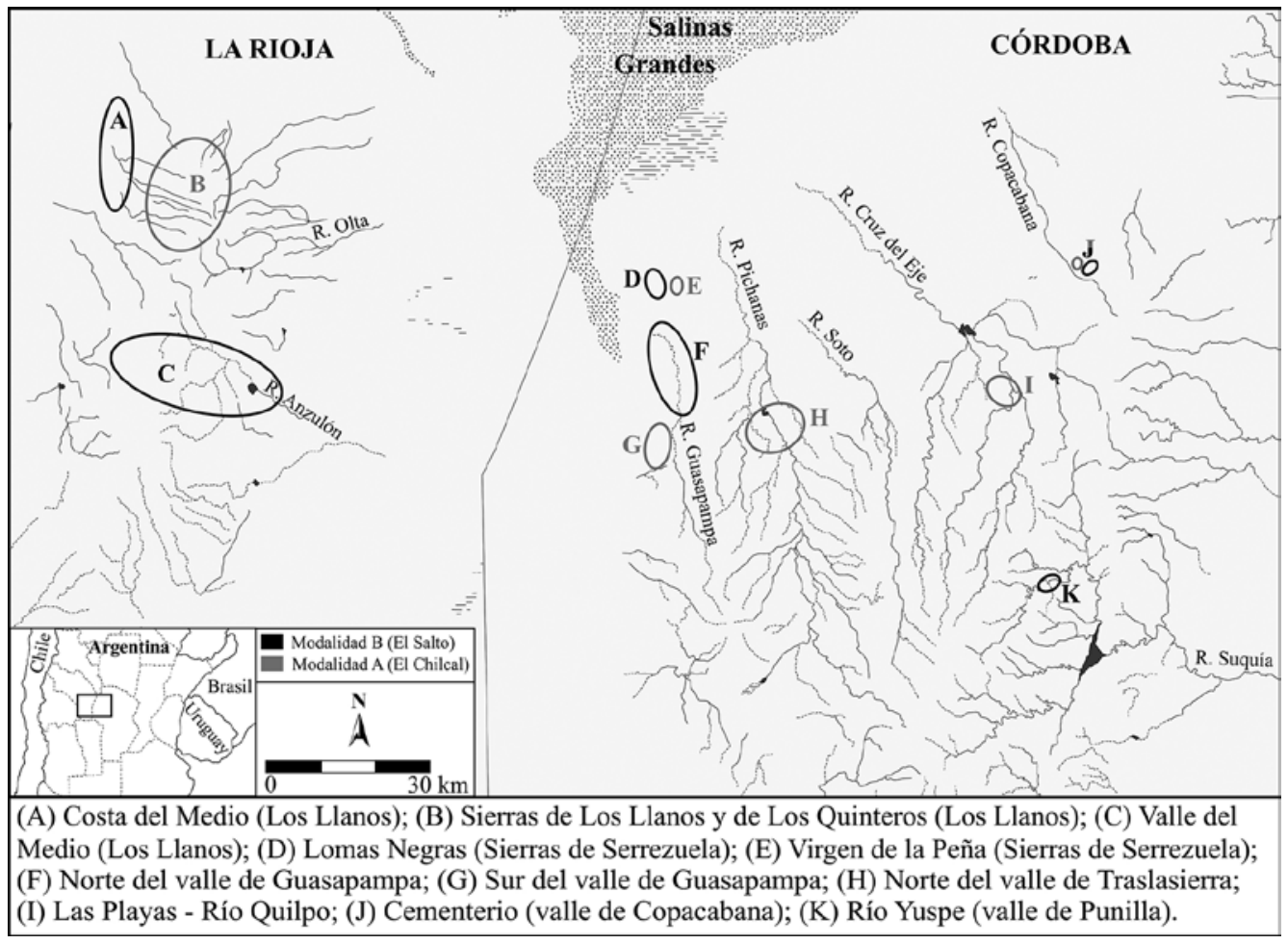

Figura 3. Distribución de paisajes rupestres entre el sur de La Rioja y el noroccidente de Córdoba. 

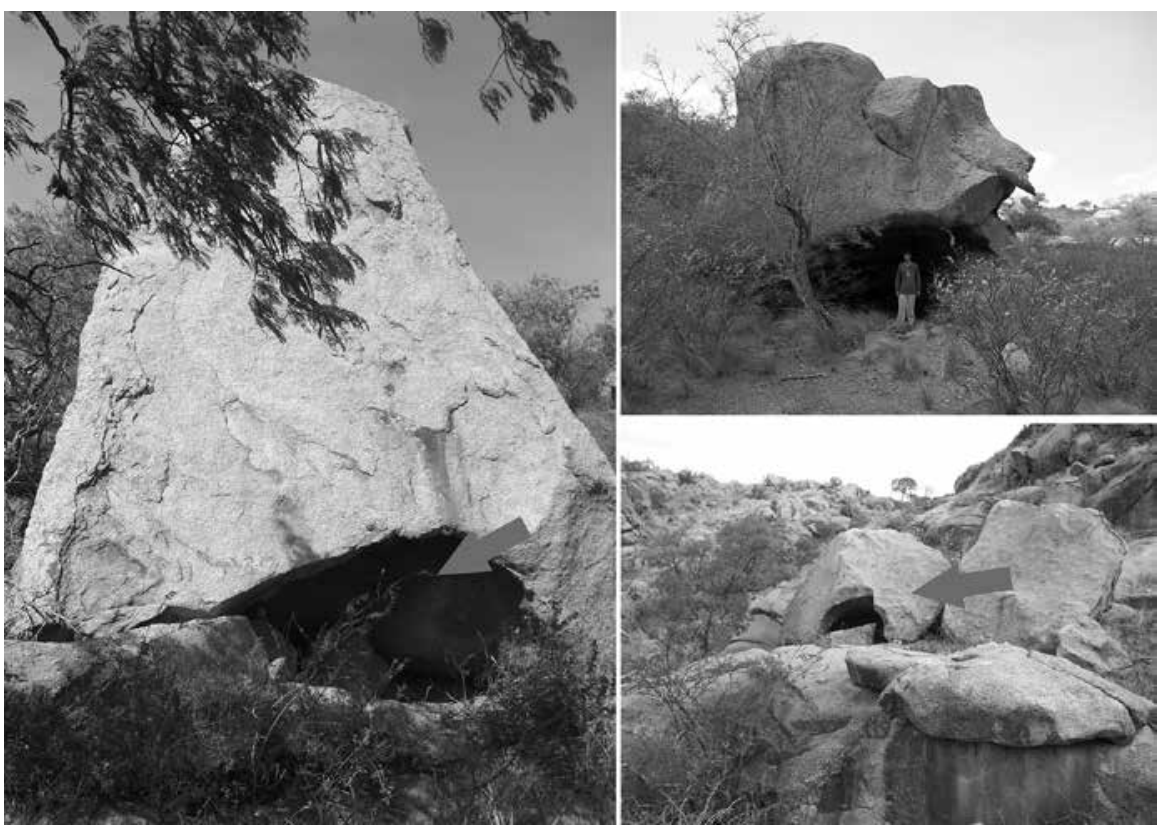

Figura 4. Abrigos rocosos donde se pintaron imágenes de la modalidad "El Chilcal".
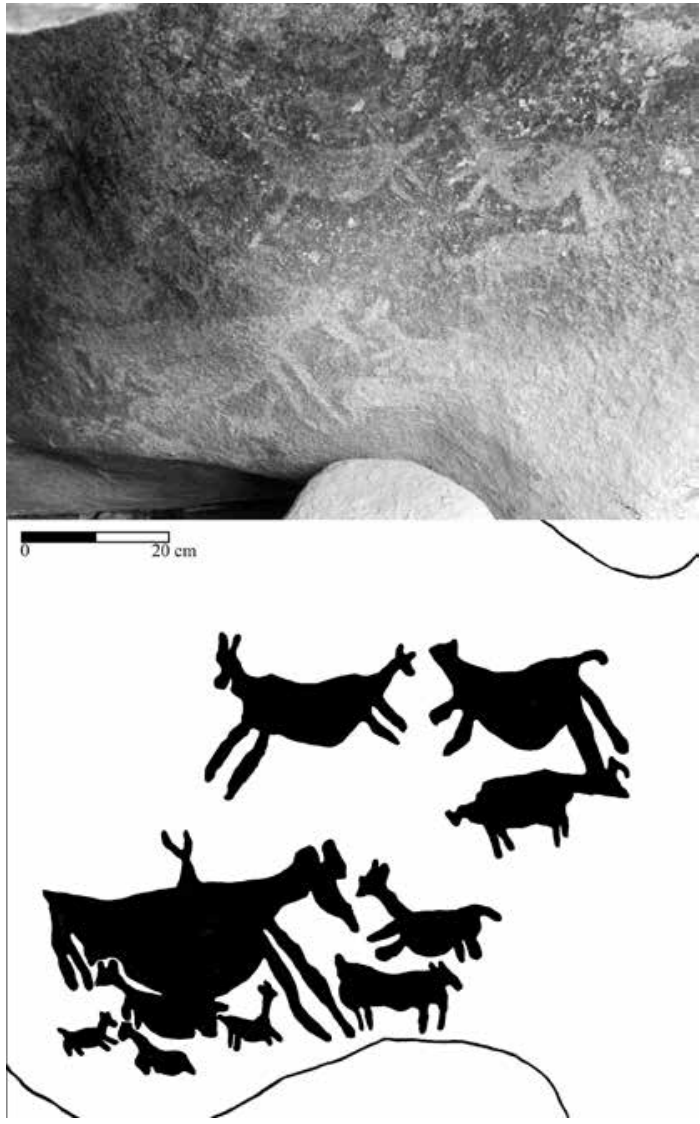

Figura 5. Camélidos pintados en el abrigo El Pircado (Sierras de Los Llanos, La Rioja). proporción se identifican otros zoomorfos, antropomorfos y motivos no figurativos. Pocas veces las expresiones de este arte se ubican en los sectores bajos de las sierras. Sus áreas de concentración se ubican en las cumbres de tres encadenamientos en particular, las Sierras de Los Llanos (propiamente dichas), las de Los Luján y las de Los Quinteros, entre 1.000 y $1.600 \mathrm{msm}$ (Figura 3 ). Se trata de un ámbito diferente al de las aguadas donde se presenta la modalidad "El Salto". Corresponde a microambientes de explotación extensiva, llevada a cabo por pequeños grupos domésticos diseminados, quienes aprovecharon los aleros y cuevas con fines de reparo transitorio.

Una lectura rápida podría atribuir cada modalidad estilística, con su patrón característico de segregación espacial, a grupos sociales con identidades diferenciadas, parcialmente expresadas en hábitos y formas de hacer disímiles. Este plano de diferenciación podría comprometer a las prácticas desplegadas en torno a la producción y significación de las imágenes pintadas o grabadas. Sin embargo, un examen más atento sugiere que no debió tratarse de dos grupos étnicos sino de dos modos divergentes de construcción del paisaje y de las relaciones sociales a propósito del acceso territorial. La modalidad "El Salto" es definida como un arte "público", como un medio de comunicación amplio e irrestricto, para propios y eventualmente extraños, durante el acceso 
y permanencia en los lugares donde se emplaza. $\mathrm{La}$ producción de las imágenes comprendería acciones de demarcación de tales locaciones, en especial de aguadas estacionales que son definidas como hitos clave de la geografía regional. Las prácticas en torno a la ejecución, observación y significación de los grabados aportarían a una construcción restrictiva en torno al usufructo de estas aguadas, por parte de unos grupos frente a otros, a partir de la apelación a referentes colectivos como entidades ancestrales concebidas como fuentes de legitimidad. Se plantea que estas imágenes en el entorno de las aguadas desempeñaron un rol activo en la construcción política comunitaria y en la instauración de una forma de territorialidad signada por un grado de exclusión.

Por su parte el arte rupestre de la modalidad "El Chilcal" es referido al ámbito "privado" de las relaciones domésticas, como parte de un conjunto de acciones (v.g. rituales) que no podían ser vistas desde el exterior de los abrigos rocosos. El acento en otros referentes iconográficos sugiere diferencias en los contextos de significación, probablemente relacionados con el campo de la cacería y con asegurar la supervivencia y reproducción de especies como los guanacos. En oposición a la modalidad "El Salto" y las exclusiones que esta tendía a imponer, las expresiones de "El Chilcal" participarían de otro tipo de construcción territorial, definida por un carácter abierto, sin la imposición de límites ni restricciones para la circulación, el acceso y la explotación de los recursos silvestres.

Vemos así que la investigación del arte rupestre prehispánico puede revelar aspectos significativos del proceso histórico local, entre ellos el desarrollo de formas rituales aportantes a la construcción de los paisajes y lugares, así como de los vínculos entre las personas, a diferentes escalas de participación y con sentidos disímiles orientados hacia la inclusión o la exclusión social. Desde otro punto de vista, y de acuerdo con los actuales objetivos, esta materialidad tiene una particular relevancia, ya que sustenta un análisis de patrones y tendencias en la circulación de información (códigos visuales, prácticas rituales, formas ideológicas) a diversas escalas espaciales. Por ejemplo a un nivel local, dentro de la región de Los Llanos, se pueden comparar las expresiones de diferentes quebradas, "costas" o serranías. Pero nos interesaremos ahora por otra escala de análisis, por la proyección extrarregional, por medio de la identificación de pautas estilísticas compartidas (técnicas, contextuales, iconográficas) con el arte rupestre de regiones vecinas, habitadas en el siglo XVI por grupos sociales con identidades étnicas diferenciadas.

En este sentido, la modalidad "El Salto" encuentra claras referencias más allá de los límites de Los Llanos. Por una parte se identifican semejanzas con el arte rupestre de las serranías y bolsones localizados hacia el occidente, como Valle Fértil, Ischigualasto, Talampaya, Paganzo y el sur de Velasco (Figura 6) (Bárcena 2010-12; Cahiza 2006-07; Falchi et al. 2011; Ferraro 2005; Re et al. 2011; Romero 2013). En todos los casos se destaca el empleo de técnicas de grabado, la elección de soportes de alta visibilidad en paredones o bloques a cielo abierto (ocasionalmente cerca de aguadas), además de numerosos elementos compartidos del repertorio iconográfico. Desde allí hacia el occidente y noroccidente, entre el norte de Cuyo y el sur del NOA, en zonas habitadas en el siglo XVI por indígenas huarpes y capayanes, también se presentan expresiones afines a esta modalidad estilística. Entre ellas mencionamos a los grabados sanjuaninos de la sierra de Pie de Palo y de las quebradas de Agua Blanca, Conconta y Colangüil (entre el alto valle de Iglesia y la cordillera), así como los grabados de Banda Florida y Villa Castelli en el oeste riojano (Callegari et al. 2009; García y Riveros 2014; López y García 2011; Romero 2013; Van Hoek 2011).

También se identifican recurrencias con el arte rupestre oriental, en las serranías cordobesas. Sin embargo esta conexión no es amplia y generalizada, como ocurre con el flanco occidental, sino que se concentra en áreas del extremo noroccidental de las sierras de Córdoba (Guasapampa, Serrezuela, Pocho), definidas como una frontera compartida con grupos de Los Llanos riojanos (Pastor 2012a, 2014). Más allá de estos paisajes, hacia el interior de la serranía cordobesa las expresiones de esta modalidad estilística se diluyen, con la excepción de sitios puntuales localizados con preferencia en el sur del valle de Traslasierra y en el oeste de las sierras del Norte y de Sumampa, en cercanías de las Salinas Grandes y de Ambargasta (Schobinger y Gradin 1985; Tissera 2014; Urquiza 2011 y observaciones propias). Otras expresiones asimismo puntuales corresponden a las sierras de Ancasti, hacia el noreste de Los Llanos, en la banda opuesta de las Salinas Grandes (Figura 6) (Quesada et al. 2014).

Obviamente señalar estos vínculos y conexiones entre producciones rupestres de zonas tan distantes como la cordillera de San Juan y las sierras de Sumampa 


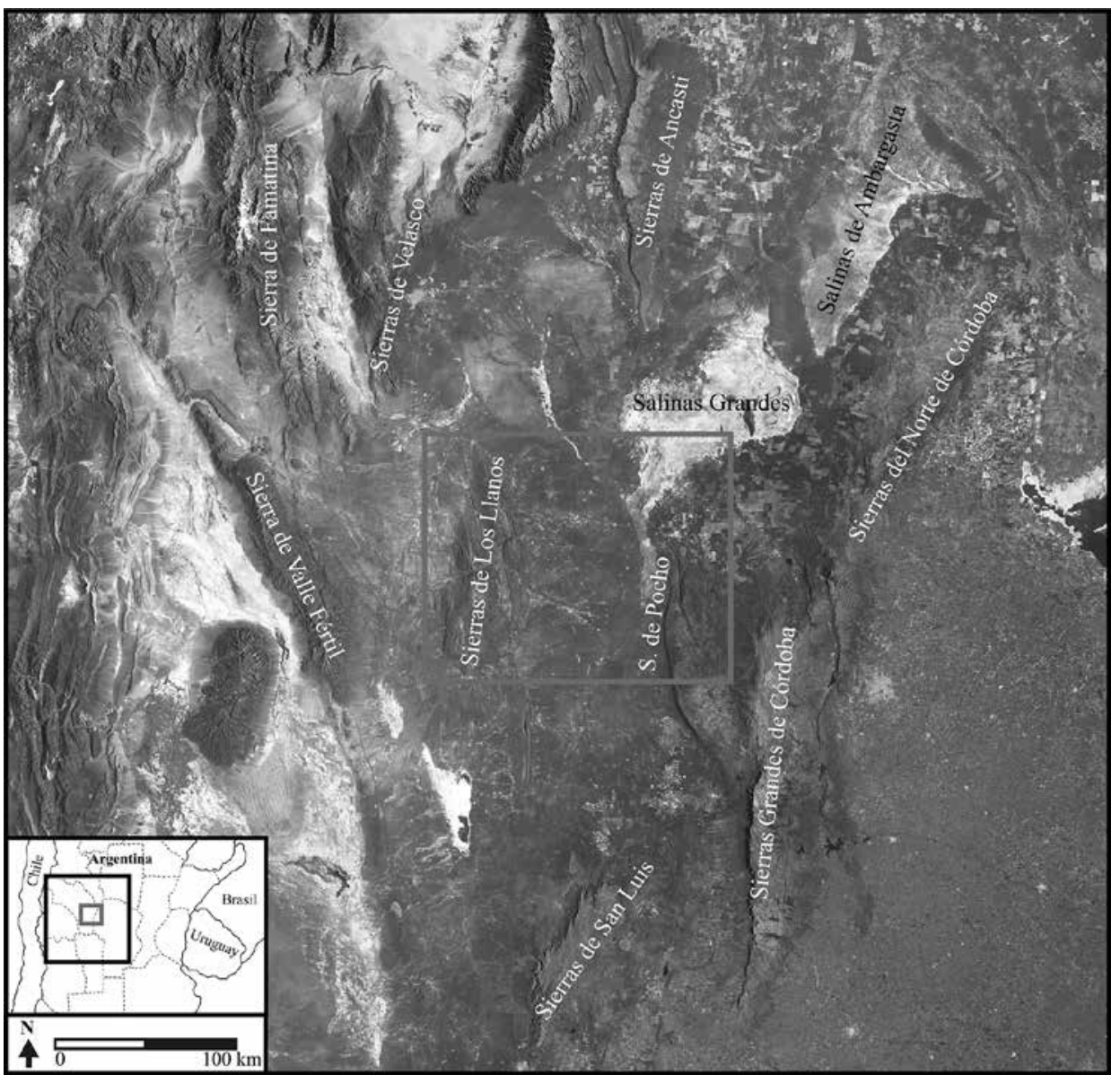

Figura 6. Los Llanos de La Rioja y el noroccidente de Córdoba en el contexto regional.

en el sur de Santiago del Estero (ca. $650 \mathrm{~km}$ en línea recta) no implica negar diferencias y particularidades locales, que de hecho existieron y son identificables. Pero en su lugar se enfatiza la recurrencia de algunas condiciones generales relacionadas con la alta exposición de los soportes y representaciones, la elección de emplazamientos cercanos a aguadas y vías de tránsito, las técnicas de grabados y la repetición de determinados motivos y temas, como los antropomorfos con rasgos jerarquizados, mascariformes, cabezas con adornos y huellas de animales, entre otros. Esta iconografía habría operado como un código visual de amplia circulación, con una tendencia a la estandarización por encima de las variaciones y especificidades, con un sentido orientado a asegurar la comunicación más allá de las diferencias, en un escenario regional multiétnico y plurilingüe.

Ahora bien, si dentro de este escenario macro nos situamos puntualmente entre Los Llanos riojanos y el extremo noroccidental de Córdoba (Figura 6), las expresiones rupestres de la modalidad "El Salto" (denominada B del lado cordobés) muestran similitudes a nivel de detalle, por encima de las particularidades, tanto en la constitución de los temas como en el diseño de los motivos y en aspectos técnicos y contextuales. Algunos ejemplos pueden ser interpretados como copias o replicaciones y de este modo, darían cuenta de una fluida circulación de personas y códigos visuales entre ambas áreas (Figura 7). De hecho, con una mirada centrada en las serranías cordobesas este tipo de arte rupestre puede ser entendido como una forma cultural extraña a las tradiciones locales, pero no obstante introducida en paisajes de frontera a propósito del incremento de los vínculos con comunidades llanistas durante el Período Prehispánico Tardío (Pastor 2012a, 2014).

En cuanto a la modalidad "El Chilcal", se desconocen expresiones de este tipo de arte en las 


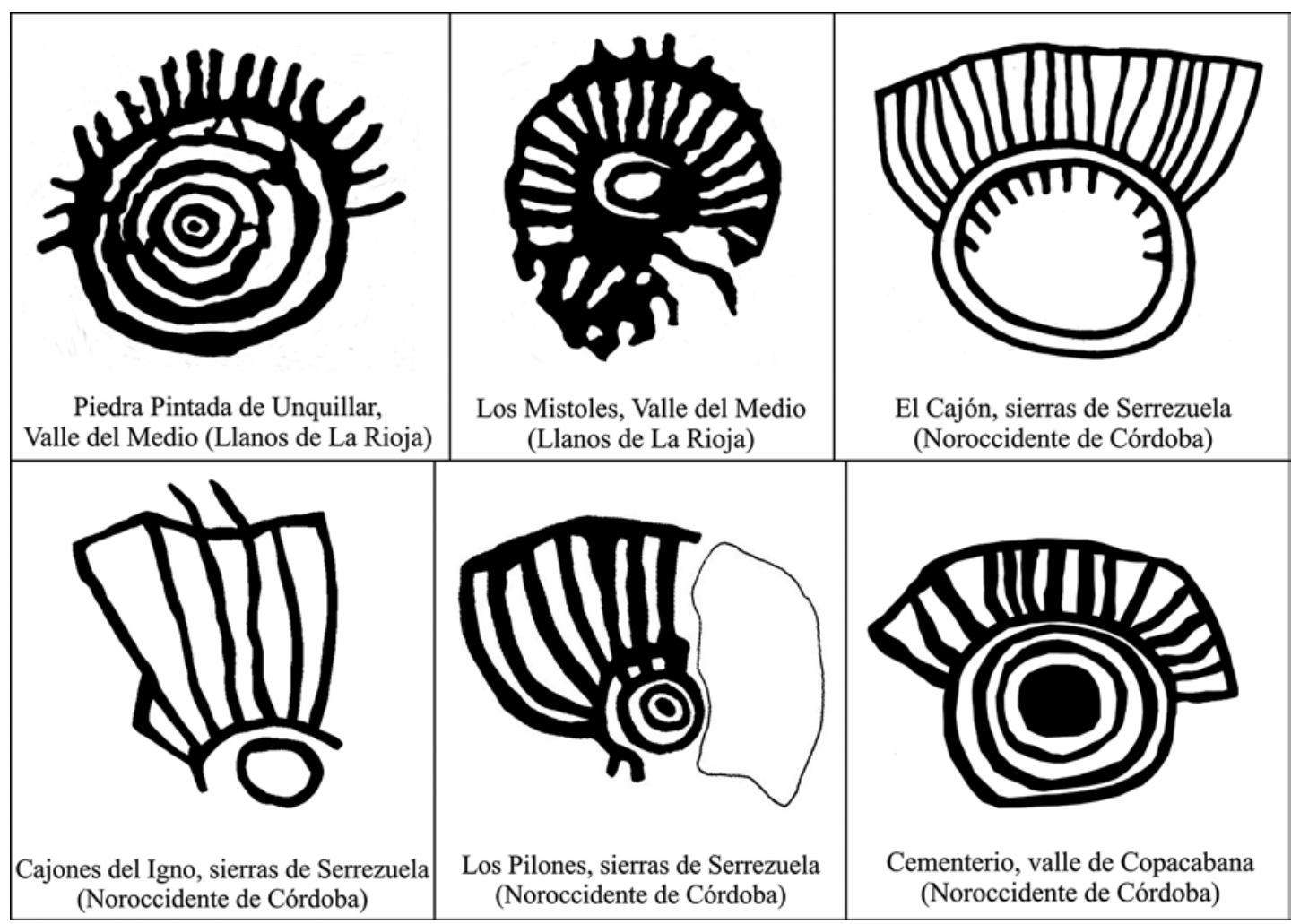

Figura 7. Motivos mascariformes con adornos radiados en sitios arqueológicos de Los Llanos riojanos y del Noroccidente de Córdoba.

áreas ubicadas hacia el occidente y noroccidente de Los Llanos, lo cual establece un marcado contraste con el patrón de alta afinidad identificado a partir de la recurrencia de la modalidad "El Salto" en ambas regiones. Por el contrario, se encuentran claras semejanzas con producciones rupestres de áreas localizadas en el flanco oriental, especialmente en la serranía cordobesa (Figura 6). Un área de concentración de este tipo de arte comprende a la serranía del extremo noroccidental de Córdoba, donde también se identifican producciones afines a la modalidad "El Salto" (o B). Sin embargo, es importante señalar que aquí también como en Los Llanos se reconoce el patrón de segregación espacial de las formas estilísticas, que tienden a distribuirse por sectores diferenciados y discontinuos. La modalidad "El Chilcal", denominada A en el oeste de Córdoba, se concentra en el sur del valle de Guasapampa (en oposición al norte del valle donde predomina la modalidad B) y en menor medida en el oriente de las sierras de Serrezuela (en contraste con la vertiente occidental donde son mayoría las expresiones de la modalidad B; Figura 3) (Pastor 2012a, 2012b; Recalde 2009; Recalde y Pastor 2012). De este modo, desde el punto de vista del arte rupestre, las serranías noroccidentales presentan mayores afinidades con Los Llanos riojanos que con el resto de Córdoba, ello evidencia un conjunto de prácticas, formas ideológicas y significados compartidos en torno a la ocupación y construcción simbólica de dichos paisajes. Durante el Período Prehispánico Tardío los procesos sociales en ambas serranías estuvieron profundamente entrelazados y no pueden ser entendidos uno al margen del otro.

En algunos paisajes particulares y discontinuos hacia el interior de las sierras cordobesas también existen expresiones rupestres afines a la modalidad A o "El Chilcal". Sin contar a varios sitios dispersos se conocen concentraciones en el norte del valle de Traslasierra (próximo a los paisajes de frontera con Los Llanos), así como en la localidad arqueológica cerro Colorado (sierras del Norte) y en el sur de Córdoba en el cerro Intihuasi (Gardner 1931; Pastor et al. 2015; Recalde y Berberián 2005; Rocchietti 2012). También en las sierras de Ancasti (oriente de Catamarca) y en las sierras de San Luis (Figura 6) se 
han registrado contextos rupestres de características similares, con emplazamientos en abrigos rocosos, técnicas de pinturas y determinadas recurrencias en los repertorios, por ejemplo camélidos de un particular canon de diseño (Figura 8) (Calomino et al. 2013; Consens 1986; Gheco 2013; Gordillo et al. 2013).

Atendiendo a la distribución de las modalidades estilísticas de arte rupestre en el escenario macrorregional $\left(28^{\circ} 05^{\prime} / 33^{\circ} 20^{\prime}\right.$ S. y $63^{\circ} 20^{\prime} / 69^{\circ} 50^{\prime} \mathrm{W}$.), con una mirada centrada en la región de Los Llanos (Figura 6), se observa que la modalidad "El Chilcal" conectó a las comunidades llanistas con una esfera de interacción, circulación de códigos visuales y prácticas sociales básicamente proyectadas hacia el flanco oriental. Esto es hacia el conjunto de la serranía cordobesa, y en menor medida hacia las sierras de Ancasti (noreste) y hacia las sierras de San Luis (sudeste). Esta esfera de interacción era diferente de aquella que tenía foco en la modalidad "El Salto" y conectaba con preferencia a los grupos llanistas con sus vecinos del flanco occidental (San Juan, oeste y norte de La Rioja).

Nos interesa destacar tres pautas relevantes para el problema que nos ocupa. En primer lugar, a nivel del escenario macrorregional se observa que Los Llanos de La Rioja participaron de las dos grandes esferas de interacción mencionadas, actuando como

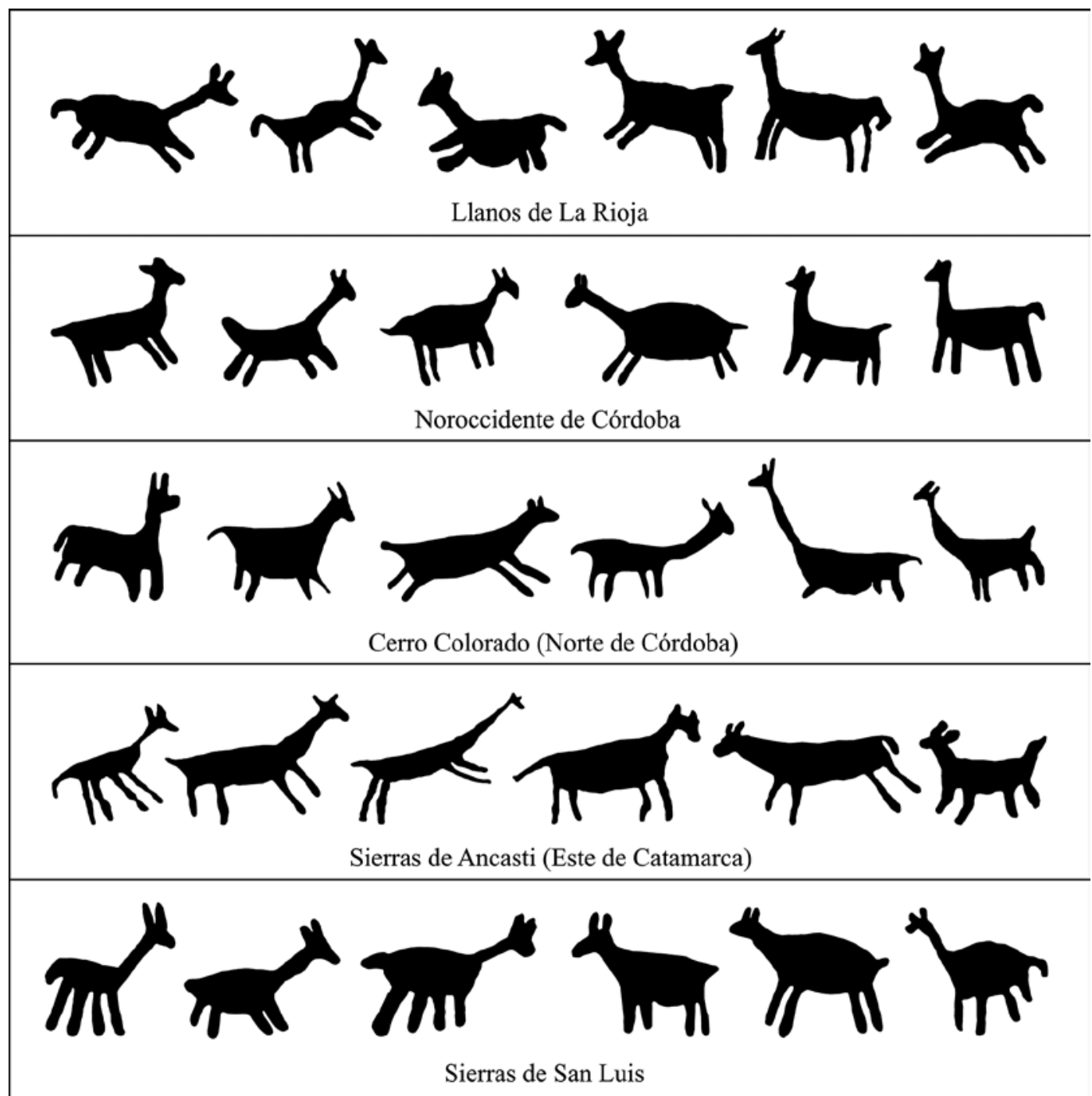

Figura 8. Camélidos del canon A (sensu Recalde y Pastor 2011) en diferentes áreas de las Sierras Pampeanas de Argentina (La Rioja, Córdoba, Catamarca y San Luis). 
límite o punto de convergencia entre ambas. Esta especial configuración, que admitió el desarrollo de ambas modalidades estilísticas no fue una pauta generalizada, sino que estuvo restringida a esta región en particular y a otras muy cercanas como las sierras del extremo noroccidental de Córdoba.

En segundo lugar, si se varía la escala para enfocar específicamente a la región de Los Llanos, se nota que este desarrollo admitido de las dos modalidades estilísticas se produjo bajo una pauta predominante de segregación espacial. Cada modalidad se desplegó por áreas acotadas y discontinuas, y dentro de cada una, por diferentes tipos de lugares como aguadas estacionales o refugios en abrigos rocosos. Las producciones de una modalidad fueron excluidas de los sitios y más comúnmente de los paisajes por donde se distribuye con preferencia la otra. A partir de vínculos fluidos y sostenidos a lo largo del tiempo con sociedades no llanistas, las comunidades locales adoptaron y adaptaron (o resignificaron) dos formas culturales que generalmente tendieron a la exclusión, y las inscribieron en sus paisajes en el marco de una compleja trama de apropiación y demarcación.

El tercer aspecto deriva de la repetición en el extremo noroccidental de Córdoba del patrón que admitió el desarrollo de las dos modalidades estilísticas en un mismo paisaje local, pero mediante expresiones diseminadas por áreas segregadas y discontinuas (Figura 3). Esta recurrencia sugiere una acentuada conexión histórica entre las dos áreas, comprometidas en un mismo proceso sociopolítico durante el Período Prehispánico Tardío, con un mismo conjunto de prácticas rituales y formas ideológicas desplegadas en torno a la construcción significativa de los diversos entornos ocupados. Si se traslada el centro de la mirada hacia las serranías cordobesas, la presencia de las modalidades estilísticas A y B (o "El Chilcal" y "El Salto") en sus límites occidentales puede ser vista como un indicador del ascendente contacto entre comunidades originarias del occidente de Córdoba (valle de Traslasierra) y de Los Llanos riojanos, con la constitución de una frontera parcialmente compartida.

\section{Diálogos renovados: Arqueología y Etnohistoria}

En este trabajo confluyen dos líneas de investigación independientes que desde distintos contextos disciplinarios exploran las conexiones entre las regiones de Los Llanos riojanos y el noroeste cordobés. Reconocer y analizar estas conexiones supuso dejar en segundo plano las conceptualizaciones que desde los tiempos coloniales hasta hoy instituyeron divisiones políticas (límites interprovinciales y jurisdiccionales) entre ellas y repensar el significado y rol de las salinas y travesías, otrora espacios marcados como desiertos inhóspitos y barreras a la comunicación entre las sociedades prehispánicas y coloniales. Los avances de estas investigaciones y la reflexión sobre informaciones, problemas y posibles interpretaciones nos permiten plantear dos hipótesis de trabajo asociadas, cuyos alcances serán puestos a prueba en las siguientes etapas de trabajo.

La primera hipótesis configura a Los Llanos riojanos como una región abierta. Tanto la información arqueológica como la etnohistórica sugieren que Los Llanos se vinculó con la región del noroeste de Córdoba. Otros indicios dan cuenta de conexiones con población asentada hacia el occidente, en el norte de Cuyo y el sur del NOA. Las salinas y travesías que recortan a la región llanista debieron ser intensamente recorridas en tiempos prehispánicos y temprano-coloniales, haciendo de estas "fronteras" parte de un escenario más amplio y complejo de intercambios sociales entre habitantes de regiones diversas y relativamente distantes. Los estudios acerca del arte rupestre señalan la presencia de dos modalidades estilísticas parcialmente integradas por elementos foráneos (v.g. iconográficos), que sugieren la apertura de la región a intercambios y relaciones, tanto del lado oriental como occidental. Este panorama es parcialmente consistente con el escenario multiétnico y plurilingüe que propone el análisis de los topónimos y antropónimos locales, con componentes de origen oriental (camiare, sanavirón) y occidental (kakano).

Las fuentes del período colonial temprano registraron que las actividades económicas marcaban ritmos de intercambio entre Los Llanos y el noroeste cordobés. Se menciona a la recolección de la algarroba en áreas parcialmente compartidas, aunque seguramente otras actividades orientadas a la explotación de los recursos silvestres eran integradas al recorrido de las travesías y la ocupación estacional de los paisajes de frontera. Entre ellas se cuentan la recolección de otras especies vegetales (frutos, semillas, raíces), de huevos de ñandú y la cacería de guanacos, cérvidos y fauna menor. Estos espacios constituyeron ámbitos de convergencia, 
donde pudieron materializarse diversos canales de intercambio, de circulación de personas e información, parcialmente plasmados en presencias comunes en la toponimia (topónimos repetidos en ambas regiones) y en la replicación de formas, técnicas y tipos de contextos en la producción del arte rupestre.

La segunda hipótesis caracteriza a Los Llanos como una región multiétnica, habitada por población de distinta procedencia (y en este sentido empleamos el concepto), como sugiere la información etnohistórica y arqueológica. Si se siguen los indicios de la toponimia este escenario de multietnicidad se habría extendido ampliamente por la región, a juzgar por la distribución de topónimos de origen kakano (Siguimán, Colosacán, Malanzán, Puluchán, Ichán, Sitán, Ambil), camiare (Mascasín, Tasquín, Tuaní, Ichila, Cantamintín) y sanavirón (Nacate, Casangate). La predominancia de una u otra lengua no implica que cada sitio constituyera un asentamiento "monoétnico" necesariamente. En este sentido fuentes tempranas indican que pueblos como Olta y Catuna (relativamente cercanos a las sierras cordobesas) contaban con una población mixta, pudiendo ser este un fenómeno extendido.

Otras fuentes analizadas sugieren que como consecuencia del proceso de conquista la convivencia o el mestizaje pudo acentuarse, debido a la dispersión de la población y los traslados compulsivos. Puluchán puede ser diagnóstico de esta situación al convertirse en pueblo de reducción desde 1611, donde se congregaba a los grupos de una misma encomienda (Puluchán y Tulain). Como vimos, en este pueblo se registraron varias personas con rango de caciques (y con apellidos de filiación camiare), pero ya no reconocidos como tales por el régimen colonial, proceso análogo al que analiza González Navarro (2013) en el noroeste de Córdoba, para los pueblos de los valles de Soto, Salsacate y Guasapampa.

No queda fuera de este esquema plantear posibles contextos de bilocalidad que entramaran a las poblaciones llanistas con sus vecinas cordobesas. $\mathrm{La}$ movilidad estacional de grupos pequeños, presididos por uno o más caciques, para acceder al agua u otros recursos era común entre los grupos del noroeste cordobés, pudiendo ser esta una pauta compartida por comunidades llanistas. En la base de estas redes de relaciones articuladas en el largo plazo debieron encontrarse los vínculos matrimoniales y de parentesco, así como las alianzas políticas, concebidos como canales de intercambio y circulación de bienes, personas y junto con ellas, de pautas culturales y formas de comunicación compartidas. Entre ellas es admisible destacar a las distintas modalidades estilísticas de arte rupestre y al bilingüismo o multilingüismo de las poblaciones, entendidos como expresión de convivencias y mestizajes.

\section{Conclusión}

En síntesis, estas hipótesis cuestionan la homogeneidad sociocultural y lingüística en Los Llanos prehispánicos y de la colonia temprana ("olongastas") y permiten plantear nuevos interrogantes. Por ejemplo, será preciso analizar con más detalle los diversos medios ecológicos, modos de vida y formas de organización política puestos en relación mediante los intercambios de población propuestos, ya que las semejanzas o complementariedades pueden dar pistas acerca de la dinámica de los vínculos entre los grupos de ambas regiones. Estamos pensando en contextos más amplios que expliquen cómo, cuándo y por qué se produjeron los avances en territorios que ya estaban ocupados por otros grupos o pueblos. La conflictividad al interior de estas regiones no puede estar ausente como variable clave en este esquema. Las fuentes españolas suelen revelar enfrentamientos entre grupos vecinos que remiten a etapas previas al contacto hispano indígena, pero aún no sabemos qué incidencia pudieron tener en las dinámicas del pasado.

El objetivo de este trabajo ha sido exponer un cuadro general del problema, a partir del diálogo y la crítica entre viejas y nuevas informaciones e ideas. La dos hipótesis delineadas a partir del replanteo de los esquemas vigentes son concebidas como puntos de partida y estímulo de las futuras indagaciones, largamente requeridas para la construcción del conocimiento histórico de la región.

\section{Agradecimientos}

A Judith Farberman, Constanza González Navarro y Andrea Recalde por la lectura crítica del manuscrito. A Carlos Zanolli, Lorena Rodríguez y Alejandra Ramos, organizadores del simposio Diversidad y posibilidades en las Etnohistorias andinas, IX Congreso Internacional de Etnohistoria (Arica, 2014) donde fue presentada la primera versión de este texto y a Jorge Hidalgo, comentarista. 


\section{Referencias Citadas}

Aparicio, F.

1939 Petroglifos riojanos. Revista Geográfica Americana XI (67): 257-264.

Aschero, C.

2006 De cazadores y pastores. El arte rupestre de la modalidad Río Punilla en Antofagasta de la Sierra y la cuestión de la complejidad en la Puna meridional Argentina. En Tramas en la piedra. Producción y usos del arte rupestre, D. Fiore y M. Podestá (eds.), pp. 103-140. Sociedad Argentina de Antropología, Buenos Aires.

Bárcena, J.

2010-12 Grabados rupestres del área de la Quebrada de la Chilca, vertiente occidental de la Sierra de Valle Fértil, provincia de San Juan, Argentina. El sitio La Chilca Pintada. Anales de Arqueología y Etnología 65-67: 89-120.

Boixadós, R. y J. Farberman

2011 Percepciones y construcciones coloniales de la "indianidad" en Los Llanos riojanos. Revista de Ciencias Sociales 20: 99-120.

Cáceres Freyre, J.

1956-57 Arte rupestre en la provincia de La Rioja (República Argentina). Runa VIII (1): 60-75.

Cahiza, P.

2006-07 Una perspectiva espacial para el estudio de las representaciones rupestres de Valle Fértil (provincia de San Juan). Cuadernos del Instituto Nacional de Antropología y Pensamiento Latinoamericano 21: 253-258.

Calomino, E.; Buono, H. y V. Zuccarelli

2013 El arte rupestre de Los Algarrobales (Dpto. El Alto, Catamarca). Primer Taller de Arqueología de la Sierra de Ancasti, Tapso (Catamarca).

Callegari, A.; Wisnieski, L.; Spengler, G.; Rodríguez, G. y S. Aumont

2009 Nuevas manifestaciones del arte rupestre del oeste riojano. Su relación con el paisaje y con otras expresiones del arte aguada. En Crónicas sobre la piedra. Arte rupestre de las Américas, M. Sepúlveda, L. Briones y J. Chacama (eds.), pp. 381-402. Ediciones Universidad de Tarapacá, Santiago de Chile.

Canals Frau, S.

1950 La población de Los Llanos. Anales del Instituto Étnico Nacional III: 67-81.

Carrizo, J.

1945 Cancionero popular de La Rioja. Vol. 1. Universidad Nacional de Tucumán, Tucumán.

Consens, $\mathrm{M}$.

1986 San Luis. El arte rupestre de sus sierras. Fondo Editorial Sanluiceño, San Luis.

Corzo, L.

1994 Polco. Editorial Canguro, La Rioja.

2009 Los Llanos. Nexo Ediciones, La Rioja.

De la Vega Díaz, D. 1994 [1945] Toponimia riojana. Editorial Canguro, La Rioja.

Falchi, M.; Podestá, M.; Rolandi, D.; Re, A. y M. Torres 2011 Arte rupestre entre las sierras y Los Llanos riojanos: localidad arqueológica Palancho. Comechingonia 15: 9-33.

Fallabrino, $\mathrm{H}$.

1971 Arte rupestre en Los Llanos de La Rioja. Ediciones Fallabrino, La Rioja.
Ferraro, L.

2005 Los Pizarrones: investigación, conservación y difusión de arte rupestre en el Parque Nacional Talampaya. Tesis de licenciatura. Facultad de Filosofía y Letras, Universidad de Buenos Aires.

Fiore, D.

2009 La materialidad del arte. Modelos económicos, tecnológicos y cognitivo-visuales. En Perspectivas actuales en arqueología argentina, R. Barberena, K. Borrazzo y L. Borrero (eds.), pp. 123-154. Editorial Dunken, Buenos Aires.

García, A. y O. Riveros

2014 Registro del arte rupestre de la vertiente occidental de la Sierra de Pie de Palo (San Juan). Primer Congreso Nacional de Arte Rupestre, Rosario.

Gardner, G.

1931 Rock paintings of north-west Córdoba. Clarendon Press, Oxford.

Gheco, L.

2013 Arte rupestre de los sitios arqueológicos de Oyola e Inasillo (Dpto. El Alto, Catamarca). Primer Taller de Arqueología de la Sierra de Ancasti, Tapso (Catamarca).

González, C.

2013 Saberes, Estado y sociedad: la trayectoria del antropólogo Salvador Canals Frau, 1930-1958. Programa de Estudios Saberes de Estado y Elites Estatales del IDES, Buenos Aires.

González Navarro, C.

2012 Una aproximación al territorio indígena prehispánico. Córdoba (siglo XVI). Andes 23: 37-70.

Gordillo, I.; Eguia, L. y J. Vaquer

2013 Primera aproximación a las representaciones rupestres en la jurisdicción de Tapso, Catamarca. Primer Taller de Arqueología de la Sierra de Ancasti, Tapso (Catamarca).

Lazzari, A.

2002 El "indio argentino" y el discurso de la cultura: del Instituto Étnico de la Tradición al Instituto Étnico Nacional de Antropología. En Historias y estilos de trabajo de campo en la Argentina, S. Visacovsky y R. Guber (comps.), pp.153201. Editorial Antropofagia, Buenos Aires.

2004 Antropología en el Estado: el Instituto Étnico Nacional (1946-1955). En Intelectuales y expertos. La construcción del conocimiento social en la Argentina, F. Neiburg y M. Plotkin (comps.), pp. 203-229. Editorial Paidós, Buenos Aires.

López, C. y A. García

2011 Análisis preliminar de los petroglifos de la Quebrada de Agua Blanca. Publicación de las VIII Jornadas de Investigadores en Arqueología y Etnohistoria del CentroOeste del País: 363-374. Río Cuarto.

Lozano, $\mathrm{P}$.

1874 Historia de la conquista del Paraguay, Río de la Plata y Tucumán. Imprenta Popular, Buenos Aires.

Martínez, J.L.

1992 Textos y palabras. Cuatro documentos del siglo XVI. Estudios Atacameños, 10: 135-150.

Montes, A.

2008 Indígenas y conquistadores de Córdoba. Ediciones Isquitipe, Córdoba.

Pastor, S.

2012a Arte rupestre, paisaje y tensión social: un caso de estudio en Córdoba, Argentina. Revista Chilena de Antropología 26: 7-32. 
2012b Arte rupestre del norte de Guasapampa y Serrezuela. Construcción del paisaje y reproducción social en las Sierras de Córdoba (Argentina). Boletín del Museo Chileno de Arte Precolombino 17(1): 95-115.

2014 Lomas Negras de Serrezuela. Construcción de un paisaje rupestre entre las Sierras de Córdoba, las Salinas Grandes y Los Llanos de La Rioja. Editorial Quire Quire, La Plata.

Pastor, S.; Recalde, A.; Tissera, L. y M. Ocampo

2015 Secuencias de producción e imposición iconográfica. Tendencias en el arte rupestre del occidente de Córdoba (Argentina). En Condiciones de posibilidad de la reproducción social en sociedades indígenas de las Sierras Pampeanas de Argentina, J. Salazar (ed.), pp. 41-83. Centro de Estudios Históricos "Prof. Carlos S. A. Segreti", Córdoba.

Piana, J.

1992 Los indígenas de Córdoba bajo el régimen colonial (1570-1620). Dirección General de Publicaciones de la Universidad Nacional de Córdoba, Córdoba.

Quesada, M.; Gheco, L.; Boscatto, S.; Vargas, P. y P. Villagra

2014 El otro arte rupestre de Ancasti. Los diseños grabados de Puesto La Mesada, El Rastro del Avestruz, La Salamanca de Albigasta y Oyola (Provincia de Catamarca). Primer Congreso Nacional de Arte Rupestre, Rosario.

Re, A.; Podestá, M. y G. Romero

2011 Ocupaciones humanas y grabados rupestres del norte de la sierra de Valle Fértil (provincia de San Juan). Comechingonia 15: 35-62.

Recalde, A.

2009 Diferentes entre iguales: el papel del arte rupestre en la reafirmación de identidades en el sur del valle de Guasapampa (Córdoba, Argentina). Boletín del Museo Chileno de Arte Precolombino 14 (2): 39-56.

Recalde, A. y E. Berberián

2005 El arte rupestre de Argentina indígena. Centro. Unión Académique Internationale y Academia Nacional de la Historia, Buenos Aires.
Recalde, A. y S. Pastor

2012 Contextos "públicos" y "privados" para la ejecución del arte rupestre en el valle de Guasapampa (Córdoba, Argentina). Latin American Antiquity 23 (3): 327-345.

Rocchietti, A.

2012 Arte rupestre: imágenes de lo fantástico. Arqueología del arte. Editorial Académica Española, Ginebra.

Romero, G.

2013 Los grabados prehispánicos del noreste de San Juan. Arte rupestre y circulación de información en ambientes áridos. Tesis de licenciatura. Facultad de Filosofía y Letras, Universidad de Buenos Aires.

Schobinger, J. y C. Gradin

1985 Cazadores de la Patagonia y agricultores andinos: arte rupestre de la Argentina. Encuentro Ediciones, Madrid.

Soprano, G.

2009 La Antropología Física entre la universidad y el Estado. Análisis de un grupo académico universitario y sus relaciones con las políticas públicas del Instituto Étnico Nacional (1946-1955). Estudios Sociales 37: 63-95.

Tissera, L.

2014 Arte rupestre y espacio público en las sierras de Córdoba (Argentina). Construcción del paisaje y reproducción social en la localidad de Achalita. Tesis de licenciatura. Facultad de Filosofía y Humanidades, Universidad Nacional de Córdoba.

Urquiza, $\mathrm{S}$.

2011 Arte rupestre de las sierras del Norte de Córdoba, Argentina. Comechingonia 15: 115-137.

Van Hoek, M.

2011 Banda Florida. An overview of a rock art site in La Rioja, Argentina. Rupestreweb: http: //www.rupestreweb. info/bandaflorida.html

Zabala, M.

2013 Las verdades etnológicas de Monseñor Pablo Cabrera. Una etnografía de archivos en la ciudad de Córdoba. Editorial Antropofagia, Buenos Aires.
1 Diario Los Principios, Córdoba, diciembre de 1932. El destacado es nuestro.

2 En contraste con otros estudios de caso acerca de poblaciones "extinguidas" (como los capayanes o los huarpes) que fueron discutidos en varios trabajos de Canals Frau, los olongastas recibieron su atención una única vez.

3 Montes registra que "olongasta" era el nombre que le daban los indios de Nono (valle de Traslasierra, Córdoba) a los de La Rioja en el período colonial temprano (Montes 2008: 526). Dardo de la Vega Díaz recoge lo comentado por Cabrera respecto del término "olongasta": con este nombre parece que designaban también las tribus cordobesas a los diaguitas de La Rioja, especialmente a los Nonogastas. Este era, sin embargo, un pueblo situado en el valle de Famatina. Y continúa con una referencia aún más general: Según Cabrera, los jesuitas de Chile hablaban en el primer tercio del siglo XVII como de terreno propicio para sus trabajos de evangelización de los Olongastas y Pampas, los cuales Olongastas no podían ser otros sino los diaguitas riojanos (1994[1945]: 230).
La designación no aparece ponderada por Luis Corzo, estudioso de la historia regional $(1994,2011)$ quien ha enfatizado la presencia mapuche, diaguita y quechua hablante en tiempos prehispánicos.

4 Cfr. el capítulo Caminchingones y Diaguitas. Sin embargo hay que notar que Montes tomó como referencia comparativa la lista de topónimos y etnónimos que figuran en el libro de Dardo de la Vega Díaz (1994[1945]) que contiene información integrada a partir de datos de muy diverso origen (documentos históricos sin registro de procedencia, saber local, obras de autoridades como Lafone Quevedo, Quiroga o Cabrera, investigaciones folklóricas, etc.). Nuestras propias investigaciones y las evidencias documentales aportadas por Montes nos permiten reconocer un número significativamente menor de topónimos y antropónimos relacionados con mayor sustento. Citamos por pares algunos de los mejor documentados (el primero corresponde al topónimo llanisto y el segundo al ubicado en las sierras cordobesas): Tulain/Tulian, Ichila-Achila/Achila-AchalaIchila (nombre de cacique), Chila/Chila, Tama/Tamahalon, 
Siguimán/Siguimán, Olayona (aguada)/Ulayon (nombre de cacique), Ampiza/Ampiza, Acalo/Acalo, Nacate/sacat ("pueblo" en lengua sanavirona), Ñoqueve/Nuquehene, Malanzán/Malanchay, Mascasín/Macatín, Ambil/Albina halon, Cantamintin/varias "docenas" de topónimos y antropónimos con el prefijo "Canta". Los pueblos llanistos de Colosacán y Catuna eran nombrados en camiare como Cocoyán y Amchalla, respectivamente. Los topónimos Nacate y Casangate tienen marcada impronta sanavirona, mientras que Mascasín y Tasquín evocan al camiare.

5 Hay varias referencias a esta cuestión a lo largo del libro. Las más certeras están en los capítulos Catuna y Sierras de los Llanos - Quininguitas y Registro de Encomiendas de Córdoba (Montes 2008: 441-442 y 579-606). Varios de estos pleitos fueron analizados por Piana (1992), como ya fuera consignado.

$6 \quad$ Un testigo natural de un pueblo de la sierra de Guasapampa declaró conocer a los del pueblo de Albina halon (Ambil, en Los Llanos) porque solía ir desde su tierra y otras veces suelen ir los indios de Albina halon a coger algarroba a la tierra de este testigo (Montes 2008: 441).

7 Las primeras encomiendas llanistas otorgadas desde $\mathrm{La}$ Rioja fueron: Nepe, Tama y Puluchán (Nicolás Carrizo), Olta (Gonzalo Duarte de Meneses), Tama, Ichila, Acalo, Tanmaha y Guayuma (Rafael Palomares), Polco, Patquía y Guayapa (Marcos de Arroyo) y finalmente Colosacán (Sebastián de Loria). Todos estos pueblos se ubicaban en el sector norte y centro de Los Llanos (y en las dos vertientes de las sierras), más próximo a la ciudad. Y al menos dos encomiendas fueron repartidas desde Córdoba, una a Alonso Díaz Caballero y otra a Antonio Aguilar Vellicia, comprendiendo pueblos de Los Llanos riojanos. Estas encomiendas se superponían parcialmente por lo que sus titulares entraron en conflicto.

8 AGI, Charcas 101, 36 (1627). Los pueblos que se citan como "visitados" son Puluchán, Santiago (sic) encomienda de Joan de Escobedo, "Atalis" (Atiles), Tama y "Cocolosa" (Colosacán).

9 Montes nos recuerda que en 1587 Gaspar de Medina llevó adelante la expedición de conquista hacia "Las Salinas Grandes y Cantacalos", ubicados hacia las sierras de Serrezuela. La encomienda concedida a Aguilar Vellicia, vecino de Córdoba, incluía al pueblo de Cantamintin, situado en Los Llanos.

10 En su estudio acerca de los padrones de la encomienda de Soto (1619), González Navarro (2013) identificó morfemas de raíz indígena que se repiten en los nombres propios de los nativos. Para la autora los mismos podrían remitir a indicadores de pertenencia a unidades suprafamiliares o linajes. Quizá “canta” pueda referir un procedimiento análogo de marca nominativa. 